\title{
Archaeological refuse fauna in Finland: Understanding the role of bone combustion
}

\author{
Samuel VANEECKHOUT \\ Archaeology, University of Oulu, \\ P.O. Box 1000, 90014 Oulun Yliopisto (Finland) \\ samuelvaneeckhout@gmail.com
}

Anna-Kaisa SALMI

Archaeology, University of Oulu,

P.O. Box 1000, 90014 Oulun Yliopisto (Finland)

Juho-Antti JUNNO

Archaeology, Institute of Biomedicine, University of Oulu,

P.O. Box 1000, 90014 Oulun Yliopisto (Finland)

KEY WORDS

bone as fuel, prehistoric subsistence, experimental archaeology, Finland, refuse fauna.
Vaneeckhout S., Salmi A.-K. \& Junno J.-A. 2013. - Archaeological refuse fauna in Finland: Understanding the role of bone combustion. Anthropozoologica 48 (1): 125-134. http://dx.doi. org/10.5252/az2013n1a7

\section{ABSTRACT}

The reconstruction of Stone Age subsistence in Finland is almost solely based on the study of burned bone assemblages from settlement sites. Seal bones dominate Stone Age refuse fauna while bird and fish bones are almost absent. The problem of the absence of bird and fish bones has been acknowledged, but so far the dominance of seal bone has been taken as a sign of (specialized) seal hunting as the main subsistence activity. In this article we question the use of archaeological refuse fauna as the single basis for the study of hunter-gatherer subsistence. We conducted a series of experiments to test how interspecies differences in bone characteristics may bias our current understanding of Finnish prehistoric subsistence. Our preliminary results clearly show interspecies differences in bone combustion qualities and in bone preservation. Further structural and densitometric analyses reveal significant differences in the medullary cavity of seal vs. terrestrial mammal bones. Our results also open new perspectives concerning the use of bone as an additional fuel source in prehistoric hearths. 


\section{MOTS CLÉS \\ Brûlage d'os, subsistance préhistorique, archéologie expérimentale, Finlande, archéozoologie.}

\section{RÉSUMÉ \\ Critique des approches aux témoins archéozoologiques en Finlande.}

L'interprétation des stratégies de subsistance en Finlande à l'âge de pierre est presqu'exclusivement basée sur l'étude de collections d'os carbonisé provenant de sites d'habitation. L'os de phoque domine les assemblages de l'âge de pierre dans la région. Les restes d'oiseau et de poisson sont presque absents. La littérature note que l'absence de l'oiseau et du poisson pourrait être due à la taphonomie, mais l'abondance relative des restes de phoque est tout de même interprétée comme indication d'une économie de chasse marine hautement spécialisée. Nous examinons ici les conséquences de l'utilisation des restes fauniques comme seule source d'interprétation des stratégies de subsistance préhistoriques. Nous présentons des résultats d'expériences qui testent l'impact des différences de matière osseuse de diverses espèces animales sur la préservation archéologique des restes fauniques. Nos résultats montrent des différences importantes de combustibilité et de préservation entre espèces ainsi que des différences de densité et de structure du canal médullaire entre le phoque et les mammifères terrestres. Nos résultats ouvrent de nouvelles perspectives sur l'utilisation de l'os comme combustible dans les foyers préhistoriques.

\section{INTRODUCTION}

Burned animal bone assemblages from settlement sites is the main source of information for the reconstruction of Stone Age subsistence in Finland. The same source has been used for the reconstruction of the post-glacial faunal history of Finland (Ukkonen 2001). Based on the fragmentary record from archaeological sites, it seems that a mixed hunting economy (elk, reindeer, birds and small mammals) existed in Finland during the Mesolithic (Ukkonen 2002). With the arrival of seals during the Holocene Climatic Optimum, seal hunting became part of the subsistence strategy on coastal sites and on the shores of the inland lakes that had a seal population. Seal bone dominated the animal bone assemblages from archaeological sites on the Bothnian coast (e.g. Halinen et al. 1996; Niskanen 1998; Heinäaho-Miettunen 2006). Usually this is interpreted as an indication of specialized seal hunting (e.g. Ylimaunu 2000) as the main subsistence strategy for the huntergatherers occupying this region. Current isotopic data suggests that marine protein resources and thus most probably seal hunting have also been an important part of subsistence strategies in coastal southern Scandinavia during the Mesolithic (e.g. Liden 1995) Unfortunately, prehistoric human bone is almost absent from coastal settlements of Finland, and thus we have to rely on artifacts and animal bones to understand subsistence.

Stone Age subsistence patterns and zooarchaeological assemblages from Finland have not been studied comprehensively. Most data on Finnish zooarchaeological assemblages resides in "grey literature" such as osteological reports. So far, the most comprehensive accounts of Finnish prehistoric bone material have been published by Ukkonen (2001) on faunal history and Mannermaa (2008) on usage of birds. Typically, a Finnish Stone Age bone sample is composed of small burned bone fragments (Ukkonen 2001: 13; 2012). Only a small number of unburned prehistoric bone fragments have been found (Mannermaa \& Ukkonen 2012). The species composition varies in different sites, areas, and periods (Ukkonen 2001: 15-18). Typically, the red squirrel, the beaver, and the arctic hare leave characteristic bone fragments that can be identified to species, whereas for instance the bones of canids, mustelids and seals can only be identified to genus or family level. 
Large species such as elk and reindeer tend to leave indeterminable long bone fragments. (Ukkonen 2001: 13-14). Seal bones often dominate the archaeofaunal assemblages from coastal Finland (Siiriäinen 1981; Heinäaho-Miettunen 2006; Mannermaa 2008: 15).

In a number of recent publications, the "specialized seal hunter" hypothesis has been opened to critique, and it has been pointed out that seal bone preserves better than bone of many other mammalian species and thus it may be overrepresented in archaeological assemblages (HeinäahoMiettunen 2006; Vaneeckhout et al. 2010). The question of preservation is especially pertinent in Finland, because bone, especially unburned bone, generally preserves very poorly in the acidic Finnish soil (Ukkonen 1993; 1997). Nearly all prehistoric bone finds from Finland are burned (Ukkonen 1993; 1997; Mannermaa \& Ukkonen 2012). The preservation of burned bone is probably due to the reduction of microbial action in the bone fragments as a result of the loss of organic matter during burning. Burned bone is very brittle and may change its shape and size, making taxonomic identification difficult or impossible (Lyman 1994: 386-390; Stiner et al. 1995; Steffen \& Mackie 2005). It has been estimated that only ca. 1 to 10 percent of prehistoric faunal remains from Finland can be identified due to burning (Taavitsainen 1980; Siiriäinen 1982).

Moreover, the cultural layers at Finnish prehistoric archaeological sites are usually very thin because of the low accumulation of organic debris in a cold northern climate with a short growing season (Rankama 1995). This causes further poor preservation and fragmentation of bone material. For these reasons, only the most durable parts of the vertebrate skeleton usually preserve in Finnish prehistoric archaeological sites. Until we have more detailed information on the effects of preservation and burning on different animal species and parts of their skeletons, we have to be cautious when making interpretations about past subsistence strategies based on faunal remains alone (cf. Nuñez 1999).

In this article we address these issues by carrying out experiments to study interspecies differences in the preservation and burning of bone. In addition, we performed structural and densitometric analyses of bones.

Differential preservation of skeletal parts and its effect on skeletal frequencies of a given animal species have received considerable attention in zooarchaeological research (Lubinski 1996, Stiner 2002). Less attention has been given to the interspecies comparison in bone preservation, although this considerably influences the composition of archaeological bone assemblages and thus affects our interpretation of past subsistence activities based on refuse fauna (Lyman and Lee 1984; Kreutzer 1992). Burning is an important taphonomic factor that affects the bone fragment size, shape, identifiability, and skeletal element representation of archaeological assemblages (e.g. Shipman et al. 1984; Stiner et al. 1995; Steffen \& Mackie 2005). In the interpretation of Finnish prehistoric animal bone assemblages, scholars usually acknowledge the poorer preservation of fish and bird bone relative to mammals (Ukkonen 2001; Mannermaa 2003, Nunez and Okkonen 1999; Nunez 1999). The dominance of seal bone, on the contrary, is taken for granted. It is usually interpreted as evidence of an economy specialized in seal hunting (Ylimaunu 2000, Ukkonen 2004; Seitsonen 2008). However, we know that the mineral density of seal bone is generally higher than that of bovids and cervids (Lyman 1994: 246-248), and that small and dense bones are more likely to be identifiable even after burning and fragmentation (Steffen \& Mackie 2005).

When considering taphonomic processes, we also have to take into account that the bone material from prehistoric settlements is not just waste material, but has possibly been used for additional purposes other than just nutrition. Other uses of bone like tool making, bone marrow extraction and the use of bone for fuel must be considered (Kankaanpää 1998; Nunez 1991).

In our experiments we studied the possible use of bone as a fuel source. This has usually been suggested in relation to wood scarcity during the Palaeolithic (Théry-Parisot 2002; Shiegl et al.2003; Niven 2007) and at northern latitudes (Hoffecker 2005; Glazewski 2006). 
Earlier experiments to compare bone and wood fuel combustion have been carried out by Théry-Parisot et al. (Théry-Parisot 2002; Théry-Parisot et al. 2005; Costamagno et al. 2005). Those experiments show that bone can be used to prolong the combustion time of a fire; the higher the proportion of bone, the longer the combustion lasts. Also significant is the fact that the mechanisms of heat transfer in bone fires are very different compared to those of wood fires. Théry-Parisot et al. (2005: 55) note that bone is preferable to wood as fuel for those activities which require the production of large durable flames.

It has been suggested that storage and the drying of bones are crucial in the use of bones as fuel (Shiegl et al.2003; Niven 2007). This has not been confirmed in other experiments. Costamagno et al. (2005) report little difference between the respective intensities of combustion in experiments with dry vs. fresh bones. Beresford-Jones et al.(2010) suggest this is due to interspecies and seasonal variation. Also following Beresford-Jones et al., we could expect that the high proportion of highly fragmented and indeterminate burned bone in Finnish refuse fauna is evidence that the bone was burned fresh and that the resulting fire was of high intensity (see also Costamagno et al. 2005 and Stiner et al. 1995).

Our combustion experiments were carried out to see if bone could have been used as fuel during prehistory and if there are inter-species differences in burning capacity. The experiment was set up as a low cost pilot study for further experimental research on prehistoric refuse fauna. Some of our results are based on observations during the experiment, and are therefore not worked out in more detail.

The distribution of the major bone components, mineral and organic, have interspecific variation (e.g. Biltz \& Pellegrino 1969). Bone mineral density (BMD) is a potential factor explaining the interspecies differences in bone combustion and post-occupational preservation of burned bones. High mineral content could reduce the amount of carbon-based compounds in bone, slowing down the effects of burning and improving preservation. We also made the assumption that bone mineral density can change during the burning process. To evaluate this hypothesis we measured the bone mineral density from non-burned and burned bone.

\section{MATERIALS AND METHODS}

The bone combustion experiment was initially set up to shed some light on the possibility of using bone as fuel. It was conducted in early December on the sandy shores of the river Iijoki in Yli-Ii. Temperature was just below freezing point, the ground was covered with snow, and there was not much wind that day.

To conduct our bone combustion experiment we collected elk (Alces alces), brown bear (Ursus arctos) and grey seal (Phoca hispida) bones from respectively a hunting association, a meat factory and local fishers. Beaver (Castor fiber), Forest Reindeer (Rangifer tarandus fennicus) and harp seal (Halichoerus grypus) were not included in the combustion experiment because of non-availability. All bones were fresh and unbroken. For wood we used dried pine and birch wood, all originating in the same lot.

We prepared six experimental fires with different contents. The fires were set up simultaneously and were used as normal campfires. Not all the combustible material was added at the same time. The influence from the environment (weather, etc.) was similar for all the fires, as they were set up in a relatively small area. A seventh fire was used as a control fire. In the control fire we used only wood as fuel source and burned bones as if they were waste to get rid off.

The six fires had different contents but the same fuel volume, approximately 961 , and size, measuring $500 \mathrm{~mm}$ by $500 \mathrm{~mm}$. We use volume in stead of weight in order to better control the size of the fires and the estimated combustion time. Differences in combustion time in this case were a consequence of differences in burning characteristics of the fires rather than of differences in fuel volume. To study the effect of different bone/ wood ratios on the temperature, we prepared three experimental fires with $75 / 25 \%, 50 / 50 \%$ and $25 / 75 \%$ wood/bone ratios. Interspecies differences were studied from three experimental fires with a 50/50\% wood/bone ratio. The fires contained elk, brown bear and grey seal bones. Similar bone assemblages were collected for these fires. The control fire had a different fuel volume and different bone/wood ratio. 
The fires were started with birch bark and small pieces of wood. Then wood was added to get the fire burning, and once enough heat was produced we added bones and wood in the same way as in a normal campfire. Pictures were taken at the same intervals as the temperature measurements were carried out. Two people were responsible for the pictures and the temperature measurements. Temperatures were measured from a fixed spot with a probe. Notes were made about the nature of the bones and about interesting phenomena which occurred during the combustion experiment.

\section{PQCT ANALYSIS}

Several aspects of the bone structure may affect the preservation of burned bone. As bone marrow contains large quantities of fat, it is assumed that bone marrow may intensify the burning process. Thus it could be hypothesized that skeletal elements rich in marrow may burn more completely and result in inferior bone preservation. It is also likely that interspecific differences in bone mineral density (BMD) may have an effect on the preservation of burned bone.

To investigate possible interspecies differences in bone structure and density parameters, we performed a pQCT (peripheral quantitative computed tomography) scan on the middle of the left tibia of each species, using XCT-960A with software version 5.20; Norland Stratec Medizintechnik GmbH, Birkenfeld, Germany.. The pQCT scan provided us with an image of the bone cross section, and in addition several parameters describing the biomechanical characteristics of the bone.

Our sample included elk $(n=4)$, reindeer $(n=4)$, beaver $(n=4)$, grey seal $(n=4)$, harp seal $(n=2)$ and brown bear $(n=4)$. Specimens were obtained from the Zoological museum of the University of Oulu. In addition to interspecific trends, we wanted to explore the difference in bone mineral density between burned and fresh bone. To conduct this part of the study we applied a pQCT -scan also on a subsample $(n=5)$ of elk femora before and after the burning process.

The following protocol was applied to the pQCT scans: each specimen was attached securely to a rigid and horizontal plastic platform with steel wires $50 \mathrm{~mm}$ apart from each other, providing parallel surface and control scale for the measurements. The slice thickness of the CT-scan was $1.25 \mathrm{~mm}$ and the voxel size was $0.69 \mathrm{~mm}$. We used a default threshold of $560 \mathrm{mg} / \mathrm{mm}^{3}$. Of the data provided by the pQCT -scan, we used the image information directly, total density (TOT_DEN), total area (TA) and cortical area (CA). Cortical densities were also evaluated from regions of interest (ROI) at tibial midshaft to examine site specific variation. These regions of interest are the sections of the bones we selected for measuring the bone density. The same region of interest (tibial midshaft) was measured for every bone to get comparable data.

\section{RESULTS}

\section{BONE COMBUSTION}

The graph in Figure 1 shows some remarkable differences in combustion properties of fires with a different wood/bone ratio. The fire with $75 \%$ bone fuel has a very fluctuating temperature. The temperature of the $25 \%$ bone fire is more stable than fires with more bones. Temperatures drop with every addition of bones as fuel. The fire with $50 \%$ bone has a longer combustion time than the fire with $25 \%$ bone. Temperatures are very similar for the $50 \%$ and $25 \%$ bone fires. The temperature was highest in the control fire.

The fire with $50 \%$ bone fuel produced more light than the $25 \%$ bone fire. The $75 \%$ bone fire did not produce enough heat to burn the bones properly. Thus, the addition of bone to fires increases combustion time and light production, however adding too much bone results in bad combustion (Figure 1).

The interspecies differences in combustion properties are also remarkable. Elk and bear bones burn very similarly. Their respective curves show a similar temperature development throughout the combustion process (Fig. 2). Seal bones burn worse than elk and bear bones, temperatures are lower and they drop every time with the addition of seal bones to the fire. The addition of elk and bear bones did not make temperatures drop as drastically as seal bone. After the combustion experiment the seal bone was 


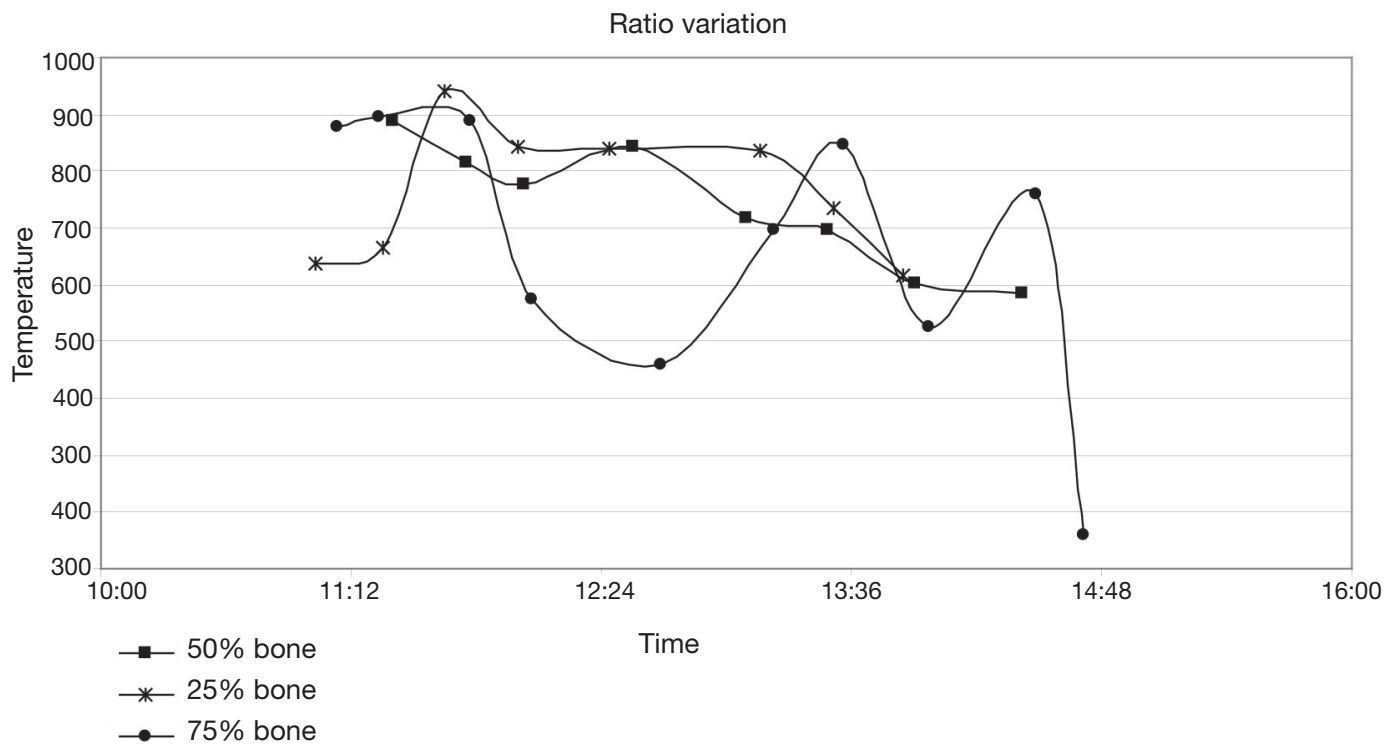

FIG. 1. - Evolution of temperature over time for different bone/wood ratios. Temperatures drop each time fuel is added. The drop in temperature is most significant for the $75 \%$ bone fire. After the final combustible material was added to the $75 \%$ bone fire, its temperature dropped very quickly.

less fragmented than elk and bear bones, though the degree of burning is similar for the three species. The bone in the control fire was most fragmented of all the fires.

The fluctuation in the temperature curves for bear and elk bones are due to the difference in combustion properties of different body parts. Rib bones and phalanges burn relatively fast and at a higher temperature compared to long bones and vertebrae. Long bones burn slower but at a more stable temperature for a longer time. However, since the bone assemblages were similar for the three fires, this factor did not skew the results of this experiment.

There are also some remarkable differences in the combustion properties of wood and bone. First of all there is the fact that when all the organic material from bones is burned the mineral part of the bone cools down relatively fast, especially with free heat conduction. At the same time there is the interesting insulating property of bone. Once the bear bone fire finished burning, the bones were piled neatly. One hour after the combustion experiment we measured the temperatures inside of what was left of the fires. The temperature of the bear bone fire was still over $400^{\circ} \mathrm{C}$. The outer layer of bone was almost cold and could be touched without protection. Temperature inside the $25 \%$ bone fire were lower than inside the $50 \%$ bone fire, one hour after the last fuel had been added. As mentioned earlier this does not hold when bone was used as the dominant fuel. Thus to some extent bone seems to be much better as an insulator than wood, except when bone is the dominant fuel source.

\section{Bone Mineral Density}

Our bone mineral density analysis explains some of these observations. Already the visual inspection indicated that there are significant interspecific differences in the tibial midshaft cross sectional properties. Beaver and both of the seal species contain only minimal medullary cavities when compared to other species (Figure 3). This trend was also proven statistically by comparing size standardized TA and CA values between our species specific subsamples (data not shown).

Our BMD analyses demonstrated a slight decrease of the mineral component of the bone during the burn- 
Species variation

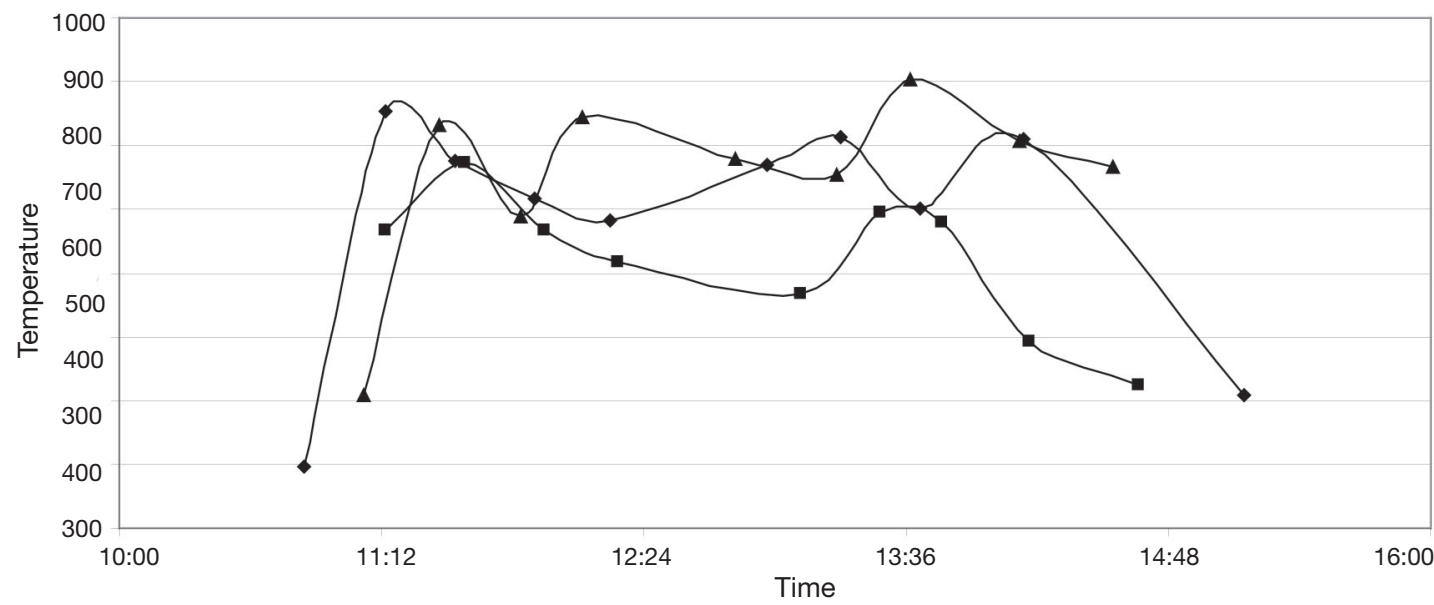

FIG. 2. - Evolution of temperature over time for different species. Elk (triangles) and bear (rhombs) fires showed similar development while the seal (squares) fire has a lower average temperature. The drop in temperature for the bear fire at the end of the curve is due to the fact that fuel finished earlier for that fire than for the other fires. The last fuel was added around 13:30 as can be seen in the drop in temperature at that time. Nonetheless, temperature remained relatively high even without the addition of fuel. For the seal fire on the contrary, fuel was still added after 13:30 but temperatures did not rise anymore. Fluctuations in the elk and bear fire are also due to differences in the type of bone added.

ing process. In fresh cortical bone the BMD observed from ROI's was approximately $1250-1400 \mathrm{mg} / \mathrm{cm}^{3}$. In corresponding burned material the BMD observed from ROI's was approximately $1200-1250 \mathrm{mg} / \mathrm{cm}^{3}$.

We could also demonstrate clear interspecific differences in the BMD values (Fig. 4; Table 1). Reindeer demonstrated highest values $($ mean $=1526 \mathrm{mg} / \mathrm{ccm})$ and bear the lowest (mean $=1308,7 \mathrm{mg} / \mathrm{ccm})$. Other species demonstrated somewhat intermediate values and thus our results have little resemblance to Lyman's (1994) suggesting higher density values for seal bone. This difference may be due to distinct analysis techniques utilized in these studies, and the fact that our analyses were performed on only the tibia.

Our conclusions on the combustion characteristics of bone are similar to those of Théry-Parisot et al. (2005). Bone can be used in addition to wood as fuel because of its particular characteristics. Bone increases the combustion time of fires. Bone and wood fires burn with a slightly lower temperature but they burn for a longer time than wood fires. Too much bone results in a very unstable fireplace which does not produce enough heat to burn all the bone. Bone also produces more light than wood

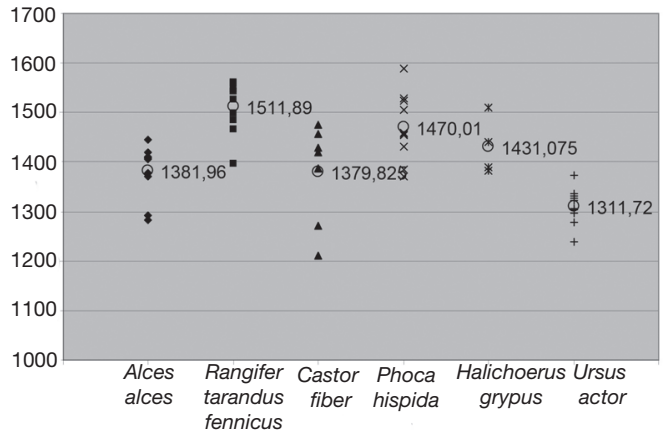

FIG. 3. - Distribution (mean and values) of non-burned Bone Mineral Density for different species.

during its burning process. In prehistoric (northern) environments, bone could have been used as a light source in dwellings. It would haven been relatively safe, since the heat produced is lower than that for fires with only wood as fuel.

Bear and elk bones seem to be more useful as fuel than seal bones. A possible explanation for this phenomenon is the relatively high bone mineral density and the almost absent medullary cavity in seal bone 


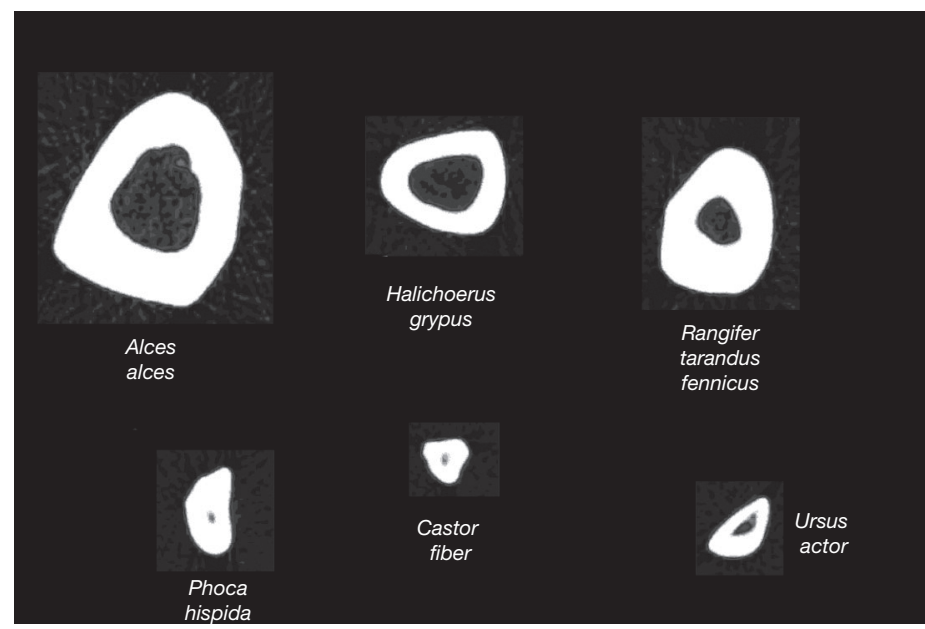

FIG. 4. - Diaphyseal cross section for mammals discussed in text.

TABLE 1. - Bone Mineral Density (BMD): mean and value range for 6 species.

\begin{tabular}{llll}
\hline \multicolumn{1}{c}{ Species(n) } & $\begin{array}{c}\text { Mean } \\
\text { BMD } \\
\text { mg/ccm }\end{array}$ & $\begin{array}{c}\text { Range (min- } \\
\text { max) mg/ccm }\end{array}$ \\
\hline 1 & Alces alces(4) & 1379 & $1292,5-1461,9$ \\
2 & $\begin{array}{l}\text { Rangifer tarandus } \\
\text { fennicus(4) }\end{array}$ & 1507,3 & $1382,3-1589,6$ \\
3 & Castor fiber(4) & 1363,7 & $1211,1-1474,6$ \\
4 & Phoca hispida(4) & 1461,3 & $1243,9-1595,6$ \\
5 & Halichoerus grypus(2) & 1450,7 & $1383,1-1530,7$ \\
6 & Ursus arctos(4) & 1308,7 & $1221,8-1373,5$ \\
\hline
\end{tabular}

(Fig. 4). Bear and elk bone contain more fat than seal bone (bone marrow contains $80 \%$ fat), partly because seals store fat under their skin while bear and elk store fat in yellow bone marrow in long bones, etc. Thus bear and elk bone burns more vigorously than seal bone, leading to more fragmentation. As a second factor, mineral density is most likely also important in post-depositional preservation of bone. Bones with high mineral density preserve better than lower density bones. It seems fair to assume that fish and bird bones have an even lower bone mineral density than mammals. The predominant preservation of seal bone is a consequence of the combination of lesser burning qualities (and less fragmentation) and high mineral density. The lesser preservation of elk bones despite their relatively high mineral density is due to increased fragmentation. A factor which intensifies the effect of differential combustion and preservation properties of bone is marrow extraction. The relatively high amount of bone marrow in elk and bear (noticed from diaphyseal cross sections) increases the probability that bones will be broken for marrow extraction. Our experiments revealed that broken bone burns considerably faster than unbroken bone.

Our experiments demonstrate that the difference in combustion characteristics and preservation of bones from different species have to be taken into account when prehistoric refuse faunas are studied. It would also be important to take into account subsistence related technology and the natural environment in the vicinity of prehistoric sites. Seal bone burns worse than for instance elk and bear bones. Similarly there is a better preservation of seal bone. These characteristics will increase the ratio of seal bone in refuse fauna compared to elk, bear, fish and bird bones.

\section{CONCLUSION}

This study focuses on the use of archaeological refuse fauna to reconstruct subsistence patterns in Finland. Our experiments open new perspectives in the study of the burned bone material in Finland. 
We suggest that bone might have been used as fuel due to its peculiar characteristics. This study also questions the dominance of refuse fauna in the study of prehistoric subsistence. Interspecies difference in combustion and preservation significantly influence the composition of archaeological bone assemblages. This has led to an overestimation of the importance of seal for prehistoric hunters in Finland. The results of these experiments should be taken into account and tested against other sources of information for the reconstruction of subsistence in Finnish prehistory.

\section{REFERENCES}

Beresford-Jones D., Johnson K., Pullen A., Pryor A., SVoboda J. \& Jones M. 2010. - Journal of Archaeological Science 37 (11): 2799-2811.

Biltz, R. \& Pellegrino, E. 1969. - The Chemical Anatomy of Bone. Journal of Bone and Joint Surgery 51:456-461.

Costamagno S., Théry-Parisot, I., Brugal, J.P., \& GUILBERT, R. 2005. - Taphonomic consequences of use of bones as fuel. Experimental data and archaeological application. in O'cConnor T. (ed), Biosphere to Lithosphere, Proceedings of the 9 th Conference of the International Council of Archaeozoology. Oxbow books, Oxford, 51-62.

GLAZEWSKI M. 2006. - Experiments in Bone Burning. Oshkosh scholar 1: 17-25.

Halinen, P., KaTiSKoski, K. \& SARKKinen, M. 1996 Yli-Iin Kuuselankankaan asuinpaikan tutkimukset 1994-1996. Kentältä poimittua 4.

HeInÄAHO-MietTUNeN H. 2006. - Yli-Iin Kuuselankankaan neoliittisen asuinpaikan palaneet luut. Unpublished master's thesis, University of Oulu.

HOFFECKER J. F. 2005. - A prehistory of the north: human settlement of the higher latitudes. Rutgers University Press.

KANKAANPÄÄ J. 1998. - Ihmisiä kylmillä mailla, in Eeva-Liisa Schulz \& Christian Carpelan (eds), Varhain pohjoisessa. Helsinki, University of Helsinki: 103-123.

Kreutzer L.A. 1992. - Bison and deer bone mineral densities: comparisons and implications for the interpretation of archaeological faunas. Journal of Archaeological Science 19.

LideN, K. 1995. - Megaliths, Agriculture and Social Complexity: A Diet Study of Two Swedish Megalith Populations. Journal of Anthropological Archaeology 14:404-417.

LUBINSKI P. M. 1996. — Fish heads, fish heads: an experiment of differential bone preservation in a Salmonid fish. Journal of Archaeological Science 23:175-181.

Lyman, R. LeE 1994. - Vertebrate Taphonomy. Cambridge University Press, Cambridge.

Mannermaa K. 2003. - Birds in Finnish Prehistory. Fennoscandia archaeologica 20: 3-29.

MannermaA K. 2008. — Archaeology of Wings. Birds and People in the Baltic Sea Region during the Stone Age. University of Helsinki, Helsinki.

MANNERMAa K. \& UKKONEN P. 2012. - Burnt Animal Bones in Occupation Contexts in Finland. European Association for Archaeologists 2012 Abstract Book: 246.

NisKanEN M. 1998. - Animal bones. In AlaKÄrPPÄ, J., IKÄheimo, J. \& OJanlatva, E.,Oulun Peurasuo 1997 - myöhäiskivikautisen asuinpainanteen kaivaustutkimus. Meteli 15.

Niven L. 2007. — From carcass to cave: Large mammal exploitation during the Aurignacian at Vogelherd, Germany. Journal of Human Evolution 53: 362-382.

NuÑEZ M. 1991. — On the food resources available to man in the Stone Age Finland. Finskt Museum 97: 24-54

NUÑEZ M. 1999. - Role of food production in Stone Age Finland. In Fogelberg, P. (ed.): Pohjan poluilla. Suomalaisten juuret nykytutkimuksen mukaan. Bidrag till kännedom av Finlands natur och folk 153. Helsinki, 133-142.

NuÑEZ M \& OKKONEN J. 1999. - Environmental Background for the Rise and Fall of Villages and Megastructures in North Ostrobothnia 4000-2000 cal BC, in Dig it all. Papers dedicated to Ari Siiriäinen. Jyväskylä, Gummerus Kirjapaino Oy: 105-116.

RANKAMA, T. 1995. - Site formation processes and vertical stratigraphy in Finland. Suomen Museo: 56-79.

Schiegl S., Goldberg P., Pfretzschner H.U. \& CoNARD N. 2003. - Paleolithic Burnt Bone Horizons from the Swabian Jura: Distinguishing between In Situ Fireplaces and Dumping Areas. Geoarchaeology: an international journal 18 (5): 541-565.

SCHUlz H.P. 2000. - Purkajasuon ja Purkajasuo/Korvalan kaivaukset. Unpublished excavation report at the topographical archive of the Finnish National Board of Antiquities, Helsinki.

Seitsonen, S. 2008. - Osteological material from the Stone Age and Early Metal Period sites in Karelian Isthmus and Ladoga Karelia, in MiKa LAVENTO (ed.) Karelian Isthmus - Stone Age Studies in 1998-2003. Iskos 16. Helsinki: 265-283.

Shipman P., Foster G. \& SChoeninger M. 1984. Burnt Bones and Teeth: An Experimental Study of Color, Morphology, Crystal Structure and Shrinkage. Journal of Archaeological Science 11(4): 307-325.

SIIRIÄINEN, A. 1981. - On the Cultural Ecology of the Finnish Stone Age. Suomen Museo 1980: 5-40.

SiIRIÄINEN A. 1982. — Recent Studies on the Stone Age Economy in Finland. Fennoscandia antiqua I: 17-26. STEFFEN M. \& MACKIE Q. 2005. — An Experimental 
Approach to Understanding Burnt Fish Bone Assemblages within Archaeological Hearth Contexts. Canadian Journal of Zooarchaeology 23: 11-38.

Stiner M., Kuhn S., Weiner S. \& Bar-Yosef, O. 1995. - Differential Burning, Recrystallization, and Fragmentation of Archaeological Bone. Journal of Archaeological Science 22: 223-237.

STINER M. C. 2002. - On in situ attrition and vertebrate body part profiles. Journal of Archaeological Science 29: 979-991.

THÉRY-PARISOT I. 2002. — Fuel Management (Bone and Wood) During the Lower Aurignacian in the Pataud Rock Shelter (Lower Palaeolithic, Les Eyzies de Tayac, Dordogne, France). Contribution of Experimentation. Journal of Archaeological Science 29: 1415-1421

ThÉRY-PARISOT, I \& COSTAMAGNo, S. 2005. — Propiétés combustibles des ossements. Données expérimentales et réflexions archéologiques dur leur employ dans les sites paléolithiques. Gallia préhistoire 47: 235-254.

UKKONEN P. 1993. - The post-glacial history of the Finnish mammalian fauna. Annales Zoologici Fennici 30: 249-264.

UKKONEN, P. 1997. — Pohjois-Suomen eläimistön historiad. Varhain pohjoisessa - maa. Department of Archaeology, University of Helsinki, 49-57.

UKKONEN P. 2001. - Shaped by the Ice Age. Reconstructing the History of Mammals in Finland during the Late Pleistocene and Early Holocene. PhD dissertation. Department of Geology, University of Helsinki.

UKKONEN P. 2002. - The early history of seals in the northern Baltic. Annales zoologici fennici 39(3).

VAneeckHout S., JunNo J., PuputTi A. \& Ä̈IKÄs T. 2010. - Prehistoric burned bone: use or refuse. Faravid 34

YlimaUnU, J. 2000. — Itämeren hylkeenpyyntikulttuurit ja ibminen-hylje-subde. Suomalaisen Kirjallisuuden Seura, Helsinki.

Submitted on 20th December 2011; accepted on 10th December 2012. 